\title{
Note from the editor Lasswell prize announcement for volume 41 (2008)
}

\section{Toddi A. Steelman}

(C) Springer Science+Business Media, LLC. 2009

The Harold D. Lasswell Prize is awarded to the best article in each volume of Policy Sciences, as determined by a vote of the journal's international editorial board. A monetary award is provided by the journal's publisher, Springer, to the awardee. The winner for the 2008 prize is David G. Ockwell for “ 'Opening up' policy to reflexive appraisal: A role for Q Methodology? A case study of fire management in Cape York, Australia”, which appeared in 41(4): 263-292.

T. A. Steelman $(\bowtie)$

Environmental and Natural Resource Policy, Department of Forestry and Environmental Resources,

North Carolina State University, Box 8008, Raleigh, NC 27695-8008, USA

e-mail: toddi_steelman@ncsu.edu

URL: http://www.springer.com/social+sciences/political+science/journal/11077 